\title{
INFORMAÇÃO JORNALÍSTICA E IDEOLOGIA: A IMPLANTAÇÃO DA DITADURA NO BRASIL EM 1964 COMO NOTÍCIA NA REVISTA ARGENTINA PANORAMA
}

\author{
JOURNALISTIC INFORMATION AND IDEOLOGY: THE \\ IMPLANTATION OF THE DICTATORSHIP IN BRAZIL IN 1964 AS \\ NEWS IN ARGENTINE MAGAZINE PANORAMA
}

Helder Gordim da Silveira ${ }^{l}$

\begin{abstract}
RESUMO: O artigo busca examinar a repercussão da consolidação da ditadura no Brasil como notícia internacional na Argentina, através do estudo de caso da revista Panorama, fundada e dirigida por Cesare Civita. Desenvolve-se, com base no conceito de ideologia e de construção social dos acontecimentos, a hipótese de que a veiculação de tais notícias, desde a posição e a atuação político-institucional da imprensa informativa empresarial, concorreu para a legitimação da solução autoritária na crise política argentina, apresentando o caso do Brasil como exemplar.
\end{abstract}

PALAVRAS-CHAVE: Imprensa; Ditadura Civil-Militar; Argentina-Brasil.

ABSTRACT: The article seeks to examine the repercussion of the consolidation of the dictatorship in Brazil as international news in Argentina through the case study of Panorama magazine, founded and directed by Cesare Civita. Based on the concept of ideology and social construction of facts, the hypothesis is that the dissemination of such news, considering the stance and the political-institutional procedure of the business press, contributed to legitimize the authoritarian solution in the Argentine political crisis, presenting the case of Brazil as an example.

KEYWORDS: Press; Civilian-Military Dictatorship; Argentine-Brazil.

\footnotetext{
* O artigo resulta do projeto de pesquisa "O Golpe Civil-Militar de 1964 e a implantação da Ditadura no Brasil como notícia Internacional na Grande Imprensa Argentina", desenvolvido na PUCRS.

${ }^{1}$ Professor do Departamento de História e do Programa de Pós-Graduação em História da Pontifícia Universidade Católica do Rio Grande do Sul - Brasil. Email: helders@ pucrs.br
} 


\title{
Introdução
}

O presente artigo resulta de um projeto de pesquisa que busca examinar a repercussão ideológica do Golpe de Estado e do regime ditatorial implantado no Brasil, em 1964, na imprensa informativa empresarial argentina. Desse universo de pesquisa, destaca-se aqui a revista Panorama, publicada pela Editora Abril, fundada e dirigida por Cesare Civita, na construção das notícias internacionais acerca daquele contexto político brasileiro.

O exame do discurso jornalístico moderno embasou-se na perspectiva teórica associada ao conceito de ideologia, atualizado em Stuart Hall (HALL, 2010). Os elementos essenciais dessa noção de ideologia que será aqui empregada - sem adentrar nos termos históricos e teóricos que condicionaram a forte polissemia do termo, dentro e fora da tradição materialista em que foi gerado - parte, com Stuart Hall, de uma definição estruturalista de Eliseo Verón:

\begin{abstract}
se as ideologias são estruturas (...), então elas não são 'imagens' e nem 'conceitos' (podemos dizer, elas não são conteúdos), mas conjuntos de regras que determinam uma organização e o funcionamento de imagens e conceitos (...). A ideologia é um sistema para codificar a realidade e não um conjunto determinado de mensagens codificadas. (...) dessa maneira a ideologia se torna autônoma em relação à consciência ou intenção de seus agentes; esses podem ser conscientes de seus pontos de vista sobre as formas sociais, mas não das condições semânticas (regras e categorias ou codificação) que tornam possíveis esses pontos de vista (...). Desse ponto de vista, então, uma 'ideologia' pode ser definida como um sistema de regras semânticas para gerar mensagens (Apud HALL, 2010: 301-302).
\end{abstract}

A partir dessa relação fundamental entre consciência/conteúdo e ideologia, Stuart Hall propõe: “desde que a tese não seja levada a uma posição estruturalista extrema, ela fornece um caminho fértil para conceituar a ideologia" (2010: 302). Nessa direção, o autor sustenta a possibilidade teórica de que a análise da ideologia consista na explicitação da "estrutura profunda" 
dos enunciados particulares, sendo esta estrutura de caráter não estritamente formal, como pressupõem posições "estruturalistas extremas", mas "histórico". Dessa forma:

a 'estrutura profunda' de um enunciado precisaria ser concebida como a rede de elementos, premissas e pressuposições derivadas dos discursos consagrados e elaborados historicamente que se acumularam ao longo dos anos, nos quais toda a história da formação social se sedimentou, e que agora constituiu um reservatório de temas e premissas nos quais (...) os emissores poderiam se inspirar para o trabalho de significar eventos novos e inquietantes (2010:303304).

Nessa direção, aponta-se para a hipótese básica aqui trabalhada, segundo a qual a construção narrativa das notícias acerca dos acontecimentos que consolidavam a ordem ditatorial no Brasil atuou potencialmente como uma ideologia da solução autoritária para a crise argentina contemporânea.

Sempre nessa perspectiva, a denominação imprensa informativa empresarial refere-se aos jornais diários e revistas, com forma, conteúdo e natureza organizacional resultantes da transição que se verifica, grosso modo, a partir das décadas finais do século dezenove, com origem marcada nos Estados Unidos e com reflexos imediatos na Europa e na América Latina. A organização empresarial moderna de jornais diários e revistas tem sua origem no modelo norte-americano dos penny papers, que aparecem nos anos 1830 e que, posteriormente, influenciariam experiências semelhantes na Europa e na América Latina, até atingirem a condição de paradigma universal da imprensa moderna. $\mathrm{O}$ surgimento e a evolução da penny press é bem estudada por Michael Schudson (2010) e outros autores. Importa aqui destacar que esse novo tipo de empreendimento representou uma inovação significativa em relação ao período anterior, nos séculos XVIII e XIX, da atividade de tipo jornalística. Esta era marcada pela relação estrita de dependência em relação ao poder político e pela forma literária de expressão. Jornais e revistas eram, naquele período, portavozes do Estado ou de partidos e movimentos, constituindo-se em meios fundamentais da expressão de opiniões e, portanto, de debate posto como 
qualificado na esfera pública burguesa (HABERMAS, 2014), em sua pluralidade de posições e interesses (CHALABY, 2003; SCHUDSON, 2010).

No intuito de proceder a uma análise teórica do produto essencial do jornalismo moderno, a notícia, serão utilizadas três categorias analíticas diferenciadas e inter-relacionadas: "fato", "acontecimento" e, finalmente, "notícia".

O "fato" pertence à ordem da exterioridade em relação ao sujeito, apresentando-se para este, portanto, como um dado de natureza objetiva, ou, se assim se disser, "real". Sem adentrar detidamente no estatuto ontológico do fato, mas imediatamente afastando a ótica positivista clássica, Muniz Sodré assim o define:

é preciso ficar claro [quanto ao fato] (...) que não se trata de objeto fora da faculdade representativa do homem, e sim de objeto do conhecimento. Desta maneira são fatos as propriedades matemáticas das grandezas, assim como o objeto de qualquer experiência possível. (...) Uma 'experiência possível' comporta um objeto, (...) um 'momento' estabelecido como um correlato do sujeito. Isto não significa que de um lado esteja o sujeito da consciência com suas representações e do outro esteja o 'fato-objeto' como uma 'coisa' existente no mundo, em si, extralinguística. Os 'objetos' do conhecimento são (...) representações sensíveis interligadas e dependentes de espaço e tempo, assim como das leis da unidade da experiência, que as tornam comuns a todos. Neste sentido, dizer objeto é o mesmo que dizer 'fenômeno'. (...) O mundo dos fatos - a que podemos também chamar de 'estado de coisas' - é o mundo da experiência empírica (2009: 28).

Essa instância de exterioridade sempre correlata ao sujeito - a qual torna possível um saber de natureza objetiva sobre o real - é a fonte empírica para o processo através do qual aqueles objetos da percepção são apreendidos na consciência subjetiva, ganhando sentido e, portanto, existência significativa. Isto é, os "fatos" só podem ser concebidos e comunicados como "acontecimentos". 
Miquel Alsina parece corroborar essa perspectiva de compreensão do fenômeno fato-acontecimento quando enuncia o que constituiria as três premissas básicas para uma teoria do acontecimento:

1) Os acontecimentos são gerados através de fenômenos que são externos para o sujeito [fatos].

2) Mas os acontecimentos [fatos] não fazem sentido longe dos sujeitos, pois são eles os que lhes conferem sentido.

3) Os fenômenos externos [fatos] que o sujeito percebe tornam-se acontecimento por causa da ação deste sobre aqueles. Os acontecimentos se compõem das características dos elementos externos nos quais o sujeito aplica seu conhecimento (2009: 114).

Parece fundamental aqui reter os dois conceitos imbricados, fato e acontecimento, nomeando-os de forma diversa, à medida que isso permite compreender o caráter rigorosamente não-ficcional da narrativa que constitui a "notícia" - o que embasa o pacto de credibilidade/veracidade que liga o jornalista a seu público-leitor.

Tal construção é geralmente pensada, no interior do campo jornalístico, em termos positivistas, que demarcam a concepção de saber na ideologia profissional da notícia. Estamos, portanto, adotando a definição de "notícia" como resultado discursivo do processo por meio do qual o jornalista profissional seleciona e hierarquiza, a partir de critérios sistemáticos de noticiabilidade, "acontecimentos" relativos a um certo espaço temático - isto é, narrativas constituídas socialmente a partir de "fatos" - para construir nova narrativa - portanto novo "acontecimento" (!) - dentro dos cânones, demandas e relações do campo, a qual se põe, ou pretende pôr-se, como saber legítimo sobre a atualidade. Assim, no intuito de proceder a uma análise deste produto essencial do jornalismo moderno em uma teoria da notícia, adotam-se aqui alguns elementos da perspectiva construtivista, fundada na tradição analítica geralmente posta como "construção social da realidade" (ALSINA, 2009: 1752; CHARADEAU, 2013: 129-151; SODRÉ, 2009: 20-135). Convém, todavia, 
considerar a advertência de Nelson Traquina, aparentemente inócua, se vista do interior da ideologia profissional:

o principal produto do jornalismo contemporâneo, a notícia, não é ficção, isto é, os acontecimentos ou personagens das notícias não são invenção dos jornalistas. A transgressão da fronteira entre realidade e ficção é um dos maiores pecados da profissão de jornalista, merece a violenta condenação da comunidade e [representa] quase o fim de qualquer promissora carreira de jornalista. (2005: 20)

Entretanto, imediatamente o autor propõe o contraste:

dever-se-ia acrescentar rapidamente que muitas vezes essa 'realidade' é contada como uma telenovela, e aparece quase sempre em pedaços, em acontecimentos, uma avalanche de acontecimentos perante a qual os jornalistas sentem como primeira obrigação dar respostas como notícias, rigorosas e se possível confirmadas, o mais rapidamente possível, perante a tirania do fator tempo (2005: 20).

Assim, no que toca especificamente ao processo de construção da notícia, a concepção de ideologia profissional, envolvendo a prática institucional e o discurso jornalístico, é compatível teoricamente, ao menos em suas linhas definidoras, com a noção construtivista de Miquel Alsina a respeito do discurso e da prática jornalística como constituintes de "mundos possíveis", articulados a um "mundo real" e a um "mundo de referência":

[o mundo possível] será aquele mundo que o jornalista construirá levando em conta o mundo 'real' e um mundo de referência escolhido. Em resumo, o jornalista não pode estabelecer qualquer mundo possível, mas precisa levar em conta os fatos que ele conhece sobre o assunto que pretende relatar, e as características do mundo de referência a que os fatos o remetem. Esse mundo possível construído (...) terá as marcas pertinentes do mundo de referência (2009: 308).

Propomos que se possa razoavelmente associar essa perspectiva do autor ao conjunto da argumentação aqui exposta. Nesse sentido: o "mundo real" corresponde à teoria do "fato", acima desenvolvida; o "mundo de referência" é 
pensado como a "estrutura profunda" não explícita dos enunciados jornalísticos (pressupostos epistemológicos, matrizes ideológicas, modelos narrativos etc.) e o "mundo possível" encontra-se associado à teoria da "notícia", como construção discursiva típica do campo - constituinte de "acontecimentos" sui generis - como se argumentou antes.

É nessa perspectiva que será empregada a terminologia de Miquel Alsina, para afirmar-se com o autor: "se no mundo 'real' era produzida a verificação e no mundo de referência era determinada a verossimilhança, no mundo possível se desenvolve a veracidade" (2009: 310. Grifos meus). É assim que Miquel Alsina chama a verificação, a verossimilhança e a veracidade de "operações de produção de sentido", as quais denominaremos, nos termos da articulação teórica acima referida, "operações ideológicas" na produção do discurso jornalístico.

Panorama e a Editoria Abril, de Cesare Civita, no Campo Jornalístico Argentino

O aparecimento da revista Panorama, em 1963, não pode ser pensado fora do contexto empresarial e sociopolítico no qual se encontra inserida esta publicação mensal de atualidades. Trata-se da Editora Abril argentina, que teria filiais no Brasil e outros países da América Latina, e da trajetória, particularmente no país platino, de seu fundador e proprietário, o imigrante italiano Cesare Civita.

Quando surge a revista Panorama, a Argentina encontrava-se sob o governo de Arturo Illia, da Unión Cívica Radical del Pueblo (UCRP), o qual estava inserido no contexto político da chamada democracia tutelada pelas Forças Armadas, desde a deposição de Perón, pela Revolución Libertadora, de 1955. A UCRP, a Unión Cívica Radical Intransigente (UCRI), liderada por Arturo Frondizi, e os principais partidos políticos nacionais (socialistas, conservadores, democrata-cristãos) disputavam o poder, na órbita federal e nas províncias, com o peronismo, o qual, embora proscrito formalmente, prosseguia 
uma força política ativa e organizada, nos setores sindical e partidário, sob a liderança, embora por vezes discutida na militância, de seu líder maior, exilado na Espanha (CAVAROZZI, 2009; DE RIZ, 2000; DONGHI, 2000; O'DONNEL, 2004; PARADISO, 2005; ROMERO, 2001; ROUQUIEU, 1994).

Peronismo e anti-peronismo dividiam politicamente o país de forma acentuada (GAMBINI, 2008). A Revolução em Cuba atuava como um extraordinário catalisador de tensões, com a radicalização das esquerdas e das direitas, dentro e fora do peronismo e das Forças Armadas, notando-se o surgimento do primeiro foco guerrilheiro em Tucumán, a partir de 1963.

O Exército, sob influência crescente da Doutrina de Segurança Nacional (DSN), dividia-se sobre a questão essencial que envolvia a integração versus a proscrição repressiva radical de um peronismo sem Perón, em uma ordem política estável, denominando-se os grupos militares azules e colorados, respectivamente (POTASH, 1994).

Igualmente recrudescia o conflito prático e doutrinário em torno de modelos de desenvolvimento econômico, fundados, respectivamente, na industrialização, de caráter estatizante, ou na agro exportação, de matriz liberal, sobretudo após o governo Frondizi, da UCRI (1958-1962). Este, em aliança com o peronismo proscrito, pusera em prática, até sua deposição pelos militares, uma política desenvolvimentista industrializante, pela via de abertura ao capital estrangeiro e ampla penetração do capital multinacional, de forte repercussão em variadas faces do âmbito sociocultural. A abertura do país ao mercado internacional, em contraste com a era peronista, refletia-se no cosmopolitismo que passava a marcar ambientes como a Universidade, as manifestações artísticas e o campo editorial e jornalístico (TARONCHER, 2009; ULANOVSKY, 2005). Neste, especificamente, verificava-se um boom de novas publicações, com destaque para as revistas aos moldes norteamericanos e europeus, sob a égide do chamado Novo Jornalismo e da geração de jovens oriunda dos cursos universitários, no qual, em parte, se insere a revista aqui analisada. 
O governo Illia, de base política bastante frágil, sob a abstenção massiva do peronismo nas eleições (CANTIS, 1995; LLAIRÓ, 2007; GIBAJA, 2008; SÁNCHEZ, 1983), via-se, assim, fustigado pelo debate em torno de uma nova ordem política nacional, sendo geralmente enquadrado em uma imagem de incompetência e lentidão frente às exigências políticas que desafiavam o país. Uma nova ruptura institucional punha-se como inevitável no processo de oposição da imprensa empresarial ao oficialismo, em um fenômeno caracterizado como golperiodismo por parte de um setor da literatura especializada (TARONCHER, 2009).

Bem antes deste contexto em que surge Panorama, Cesare Civita iniciava sua carreira no setor editorial, em 1936- após experiências profissionais da juventude, nos Estados Unidos e na África - na Itália, sob o regime de Mussolini, quando ingressa na empresa de Arnoldo Mondadori, editando a publicação de revistas voltadas ao público infantil com os personagens de Walt Disney. Com a edição das chamadas leis raciais, em 1938, Civita, membro da comunidade judaica, vê-se na contingência de deixar o emprego e o país, recebendo, a título indenizatório pela dissolução do contrato de trabalho, os direitos de publicação sobre os personagens e as histórias em quadrinhos que editava (SCARZANELLA, 2009 e 2016).

Tenta inicialmente estabelecer negócios editoriais, com os direitos sobre os personagens de Disney, em Paris, posteriormente Londres e, já no transcurso inicial da Guerra, em 1941, obtém visto para os Estados Unidos, fixando-se brevemente em Nova York, cidade onde nascera, de pais então imigrantes italianos temporários, e para onde viajava com frequência e estadas prolongadas, após o retorno da família ao país de origem. Será neste segundo período de exílio que Civita obterá, diretamente junto ao grupo empresarial de Disney a representação para a venda de direitos sobre os personagens infantis no mercado sul-americano, então ainda por explorar.

Seria, então, com Mickey Mouse, Pato Donald e cia. na bagagem que Cesare Civita, após passagem pelo Rio de Janeiro, chegaria em Buenos Aires. Era maio de 1941 e, ao longo dos próximos trinta anos, o imigrante construiria 
um império empresarial que o colocaria no centro do setor editorial argentino. O núcleo do império seria criado no final do mesmo ano, reunindo sócios da comunidade argentina de imigrantes judeus italianos: a Editora Abril.

Voltada inicialmente ao público infanto-juvenil - nicho com relativamente poucos concorrentes em um mercado editorial em rápida expansão desde 1936, quando a Guerra Civil na Espanha interrompeu a tradicional importação de livros deste país, dando início a um processo substitutivo na área (SCARZANELLA, 2016: 19-50) - a Abril publicaria a coleção Pequeños Grandes Libros, da qual faziam parte histórias com os personagens Disney, que alcançou enorme sucesso, chegando à marca de um milhão de exemplares dos livros por ano (SCARZANELLA, 2009: 68). Em 1944, a editora obteria os direitos para a publicação de revista exclusiva com histórias em quadrinhos dos personagens estadunidenses, a qual Civita denominou El Pato Donald, vivendo então a Argentina o primeiro ano do novo regime inaugurado pelo golpe dos coronéis, de 1943.

As relações de Civita com a nova ordem que projetaria Juan Domingo Perón ao centro do poder seriam marcadamente conflituosas. Apesar de estabelecer contratos com empresários de origem italiana ligados ao regime de Mussolini, notadamente no setor gráfico argentino, Civita ostentava posição política abertamente antifascista, inclusive participando da publicação do semanário Itália Livre, juntamente com vários intelectuais compatriotas, dentre os quais o sociólogo Gino Germani.

Todavia, os problemas começaram de fato quando a Abril passou a oferecer empregos - e abrigo - a inúmeros profissionais progressivamente perseguidos pelo regime por suas posições políticas: socialistas, comunistas e, em seguida, antiperonistas de esquerda. Sobre este período inicial da trajetória empresarial de Civita e suas relações com o primeiro peronismo, refere Eugenia Scarzanella:

Abril se caracterizó (...) desde sus orígenes como una
empresa particular en el panorama editorial argentino.
Es un lugar donde se encuentran y trabajan
intelectuales marginados por sus ideas políticas 
antifascistas y antiperonistas, socialistas y comunistas y al mismo tiempo es una empresa exitosa en el ámbito de la cultura popular de masa. Ambas vocaciones (...) se mantendrán en el tiempo y la expondrán en el contexto de la débil democracia argentina de posguerra a críticas y ataques (2009:70).

No pós-guerra, assim, as relações da Abril e de Civita com o regime peronista seguiriam tensas e contraditórias. $\mathrm{O}$ mercado editorial das revistas em quadrinhos de origem estadunidense conhece então um período de forte expansão, mercê de uma das faces da chamada política da Boa Vizinhança, dos anos 1940. A Abril aproveita com sucesso as oportunidades do contexto, expandindo as publicações tradicionais com os personagens Disney, tendo $E l$ Pato Donald à frente, e lançando revistas com novos personagens estadunidenses e italianos.

Da Itália, igualmente, Civita traria para a Argentina, a partir de 1948, um novo produto do mercado editorial de entretenimento que conheceria rápido e estrondoso sucesso: a fotonovela. Inicialmente publicando as produções italianas da editora de seu antigo empregador e amigo Mondadori - com atores e atrizes de grande sucesso também no cinema, como Sofia Loren, Amedeu Nazzari e Gina Lollobrigida - , Civita logo criaria um núcleo nacional de produção de fotonovelas, com atores, atrizes e técnicos argentinos e italianos, o qual redundaria no extraordinário êxito editorial da revista Idílio, a qual atingiria no período a marca de 250.000 exemplares semanais (SCARZANELLA, 2009: 74). Assim, no final da primeira era peronista, a Abril tinha posição consolidada no mercado argentino, projetando sua expansão na América Latina.

Após a queda de Perón e o início da referida democracia tutelada pelos militares (1955-1966) - em um contexto de forte internacionalização da economia, da sociedade e da chamada cultura de massa na Argentina - a Abril intensificará seu processo de expansão, diversificando suas publicações, investindo no setor industrial gráfico e apostando na consolidação de suas posições empresariais na América Latina, com destaque para o Brasil. 
No que toca ao investimento no setor industrial, a editora de Civita firmará sociedade com a Fabril Financiera, empresa que até então era contratada para impressão das revistas da Abril. A Fabril era então um poderoso grupo empresarial, que mantinha boas relações com certos círculos políticos e militares, decisivos no novo contexto do país e que mantinham restrições nacionalistas em relação, agora, ao caráter internacional das articulações empresariais da Abril. Além dessa nova sociedade com o ramo gráfico, Civita investiu na instalação de uma planta industrial do setor, próxima a Buenos Aires, em 1963, tal como já fizera em São Paulo, desta vez importando maquinaria e técnicos da Itália e da Suíça.

$\mathrm{Na}$ esteira do aludido processo de diversificação de publicações, para além dos quadrinhos, livros infantis e fotonovelas, surgirão duas novas revistas de sucesso: Claudia, em 1957, e a aqui importante, Panorama, em 1963. Sobre as duas novas revistas da Abril, refere Eugenia Scarzanella:

Claudia y Panorama ('La revista de nuestro tiempo') son termómetros de la fiebre modernizadora argentina. Se imitan revistas extranjeras (...) como antes se habían imitado los tebeos, los libros para niños y las fotonovelas argentinizando los modelos originales. En este período aumenta el impulso a crear un producto que no sea local, sino que pueda atraer a lectores de otros países latino-americanos. No sólo (...) las nuevas publicaciones de Abril constituirán un modelo para revistas destinadas al público de lengua portuguesa de Abril brasileña, sino que Claudia y Panorama conquistarán mercados de países vecinos (Uruguay, Chile, Colombia, Perú, Centroamérica) y se creará una sociedad mixta en México, la Mexabril (2009: 80).

A autora sustenta que, desde o início dos anos 1950, Civita planejava editar uma revista de atualidades no estilo da italiana Epoca, do amigo Mondadori, mas que não vira oportunidade concreta para tanto até 1963, quando lança Panorama, em acordo com o editor italiano e com o grupo estadunidense Time-Life (2009: 77). Especificamente sobre a revista, refere:

Panorama, tal como las revistas contemporáneas Primera Plana y Confirmado, se dirige a un público [de classes alta e média] deseoso de adecuarse a los 
consumos y los valores de las sociedades occidentales más avanzadas. (...) Como su homólogo italiano de Mondadori, es una revista de tipo nuevo, que no apuesta ya sólo a los servicios fotográficos (dado que a ese punto la televisión ya responde de manera más eficaz que la prensa al pedido de un 'periodismo por imágenes'), sino que privilegia el texto escrito, adoptando un estilo sobrio, llevando a cabo investigaciones, brindando 'noticias incómodas'. (...) La presentación gráfica (...) mejora gracias a la importación de maquinarias italianas. Con el intento por mantener 'los hechos separados de las opiniones' como había propuesto Times antes que nadie, se aspira a 'hacer una revista que merezca el respecto de todos los sectores dirigentes del país' (2009: 79-80).

Carlos Ulanovsky informa que o primeiro número de Panorama, com 132 páginas, esgotou-se em 48 horas. E acrescenta:

en la edición inicial se explicaba el funcionamento de esa especie de redacción 'doble', una en Buenos Aires y otra en Nueva York, 'que selecciona material de acuerdo con las directivas enviadas desde Buenos Aires. Desde la redacción de Time, en la Avenida de las Américas, Nueva York, se despachaban hacia el sur más de dos millones de palabras'. Y desde aquí viajaban periodistas para especializarse (2005: 223).

Sobre as características formais e de estilo da revista, afirma o autor:

ofrecía notas en color - mucho antes que la TV cromática -, en especial la de temas extranjeros; presentaba un movimiento informativo inusual apoyado en el tratamiento in extenso de cuestiones que los diarios no trataban o a las que conferían espacios mínimos; le daba gran importancia a los enviados especiales. En el número 1 había 7 notas locales y 20 internacionales (2005: 223).

Destaque-se assim a vocação da revista, voltada ao noticiário internacional, pelo predomínio e extensão das matérias, assim como pela utilização bastante frequente de enviados especiais, o que se verá na cobertura do golpe de Estado no Brasil.

A chefia de redação ficou inicialmente a cargo de Jorge De Ángelis, cidadão italiano, genro de Civita, casado com Adriana Civita, jornalista que 
ganharia destaque no campo, sobretudo pelas matérias que produzia infiltrandose sob disfarces nos meios sociais em situação de marginalidade, na busca pela chamada informação direta, procedimento jornalístico muito pouco usual na época.

A trajetória de Panorama no período 1955-1966 encontra-se perfeitamente inserida nos caminhos e posições da Abril, assim sumariados por Eugenia Scarzanella:

durante la breve temporada democrática entre 1955 e 1966, Abril amplió sus productos de manera que con una prensa femenina moderna y con las revistas de actualidad llegó a tocar âmbitos más expuestos a la tentación de censura por parte del poder político. La editorial mantuvo e desarrolló en esos años su característica de catalizador de intelectuales de oposición, abriéndose a las novedades culturales de la época. Desde el arte pop al psicoanálisis sus revistas ponían de manifiesto un clima cultural en fermento, que tenía en el Insituto Di Tella su centro propulsor. Muy pronto, sin embargo, las críticas al estilo de las publicaciones de Abril comenzaron a provenir no sólo de los sectores tradicionalistas y conservadores, sino también desde los sectores de la izquierda radical y atiimperialista, hostiles hacia la cultura yanqui (2009: 88).

Esse aparente paradoxo nas fontes de críticas à Abril e suas publicações, frente ao projeto editorial próprio do grupo e seus objetivos jornalísticos e empresariais, particularmente no caso de Panorama, deve, assim, ser considerado no exame da cobertura da revista da crise no Brasil e do golpe de 1964 no país vizinho. Assim como condicionará a trajetória posterior do grupo, após o golpe de 1966 na Argentina, o retorno do peronismo ao poder, em 1973, e, finalmente, a ditadura implantada em 1976, quando Civita se vê na contingência de vender seu império editorial na Argentina e partir para novo exílio.

O Golpe no Brasil em Panorama: Singularidades Nacionais e Lógica do Mercado 
Para o presente artigo, foram considerados oito exemplares mensais de Panorama, entre maio e dezembro de 1964. Destes, o Brasil foi objeto de longas reportagens em três edições. Essa cobertura de Panorama do golpe de Estado no Brasil e de seus desdobramentos iniciais, ao longo do ano, segue o estilo das matérias de destaque da revista de Civita. Vê-se uma combinação de elementos da foto-reportagem - apresentando imagens que, por vezes, ocupam praticamente todo o espaço da página, entremeadas de textos curtos alusivos àquelas - com textos longos, de forte teor analítico, acerca do fato, certamente produzidos por Correspondente ou Enviado Especial, embora as matérias não tenham autoria indicada.

De forma geral, verificam-se, nas matérias aqui examinadas, uma articulação de dois eixos temáticos ou argumentativos. De um lado, procuramse estabelecer as razões, a natureza e os desdobramentos potenciais da crise política brasileira e do golpe como culminância dela; de outro, procura-se delinear uma imagem das características socioculturais e históricas, postas como definidoras de uma identidade nacional brasileira. Ambas as linhas argumentativas irão articular-se nas operações ideológicas de verificação e verossimilhança para produzir o efeito de veracidade na construção do acontecimento no país vizinho.

A manchete da matéria inicial da cobertura é significativa nesse sentido: "Brasil: Gigante en Crisis" (maio de 1964). Um gigantismo e a complexidade social, histórica e cultural, potencialmente em contraste, nestes aspectos, com a Argentina, são sempre associados aos condicionamentos da crise política presente e suas possíveis evoluções futuras. A manchete tem como pano de fundo, ocupando toda a página que abre a matéria, a imagem de militares perseguindo civis, em rua do centro do Rio de Janeiro, no dia posterior ao golpe, em uma operação básica de verificação associada à verossimilhança, por sua vez calcada em imaginário jornalístico atualizado na Argentina, pelo menos a partir de 1955, com respeito a intervenções militares na ordem política e a presença de tropas nas ruas, com seus significados potenciais enquanto estrutura profunda, ou mundo de referência, do discurso imagético. 
O texto breve, colocado no canto direito superior da página, sumariza e guia a leitura das páginas subsequentes: "una revolución incruenta puso término a la caótica administración de Goulart y demostró que la quiebra financiera no se soluciona con gestos demagógicos" (maio de 1964: 29). Para além do evidente tom legitimador do golpe, verificável em leitura superficial do breve texto-guia, notam-se neste texto elementos mais profundos que serão desenvolvidos no restante da matéria e mesmo nas reportagens seguintes.

Primeiramente, a adoção do termo "revolução", pelo qual se auto denomina o golpe no Brasil, para caracterizar a intervenção militar, remete a um universo de significação constituído por elementos associados a um estado de crise mais ou menos profunda, por um lado, e, por outro, de ruptura radical e instauradora de nova ordem política, destinada, a princípio, a perdurar no tempo. O termo "incruenta", pelo qual se adjetiva a revolução, ao mesmo tempo que expurga do acontecimento a violência, que seria "natural" num quadro de referência consolidado a respeito de "revoluções" no Ocidente, remete à forma de reação social mais ampla ao fato "revolucionário", potencialmente classificável por passividade. A expressão "quebra financeira" remete, por seu turno, à natureza essencial daquela crise, assim como as menções ao "caos administrativo" na ordem deposta - centralizada na figura de Goulart - é associada às significações negativas do termo "demagogia", postas em um universo de referência constituído pelos elementos do que acima denominamos liberalismo profissional do campo.

Tais elementos, potencialmente acionados para o exercício interpretativo do leitor suposto, são desenvolvidos na sequência imediata da matéria. Em página composta quase inteiramente por imagens fotográficas, tem-se, na metade superior, um quadro panorâmico do comício de 13 de março, no Rio de Janeiro. Nele, emergem, acima da multidão, cartazes nos quais se destacam, a uma primeira visão, a sigla PCB em vários deles, com o símbolo da foice e do martelo aparecendo em um cartaz centralizado na imagem. Um leitor argentino mais atento e disposto a ler dizeres em português veria referências nos cartazes a "votos para os soldados", "legalidade para o PCB", assim como 
menções aos direitos dos marinheiros, aos operários da ELETROBRAS e às reformas agrária e urbana. Na metade inferior à esquerda da página, vê-se outra imagem, na qual, em enquadramento aproximado, ao fundo, estão pessoas que o texto explicativo informará tratar-se de "camponeses", armados com rifles de cano longo, apontados para cima e, em primeiro plano ao centro, a figura de um sacerdote católico, caracterizado pela batina escura, com o braço esquerdo elevado, a indicar um sinal de liderança, e empunhando, na mão direita posta à altura da cintura, um revólver, de calibre alto e com o cano voltado para cima, como os rifles das figuras ao fundo.

A composição das duas imagens na página, com seu evidente impacto emocional, expressa, com este viés, a operação ideológica verificadora acerca da realidade dos fatos, com base no peso da imagem fotográfica como janela para aquela realidade, no interior da ideologia constituinte da transparência perfeita dos ditos fatos. É nesse sentido que os textos breves, complementares às imagens, compõem o quadro verificador nesta ideologia da (re)constituição do fato, isto é, na construção do acontecimento jornalístico associado à categoria notícia, segundo a discussão acima posta. É assim que o primeiro destes textos, que se encontram formando uma coluna no canto inferior direito da página, pode informar aos leitores argentinos: "el 13 de marzo se reunieron 200 mil personas en Río para escuchar a Goulart anunciando medidas de córte izquierdista que satisfacian indudablemente a los comunistas, muchos de los quales portaban carteles con la hoz y el martillo" (maio de 1964 : 30. Grifo meu). Desnecessário mesmo referir a operação de verossimilhança calcada no conjunto de princípios anticomunistas de um mundo referencial evocado.

$\mathrm{Na}$ mesma direção, o texto seguinte estende a reconstituição dos fatos que antecedem ao golpe, todos assim colocados, segundo a lógica interna do discurso, na condição de causas deste: "los proyectos de reforma agraria crearon odios entre campesinos y terratenientes en el nordeste brasileño , que foran aprovechados por personajes tan extraños como el pretendido sacerdote Magalhães Mendes, para formar piquetes armados" (Idem). No acontecimento, o fato remete imediatamente à verossimilhança de um mundo de referência 
composto pela noção genérica de luta de classes através do substantivo "ódio", a qual é explorada com fins evidentemente políticos, por uma figura "estranha", por sua vez associada a um universo referencial religioso de significações amplas e conflitantes no contexto político-cultural argentino.

O terceiro texto complementa assim as informações: "el amotinamiento de infantes de la marina, en Río, y su posterior tratamiento ajeno a la disciplina militar, fue una de las causas de encono en las filas armadas contra el régimen de João Goulart" (Idem). A noção de "causa" é aqui diretamente enunciada em uma associação do fato representado pelo motim dos marinheiros no Rio de Janeiro e a reação presidencial a ele, cujo significado remete à quebra do sistema hierárquico, fato de essencial relevância no mundo referencial acerca da instituição militar.

Com base neste poderoso lastro informativo - no qual fatos remetem a mundos referenciais que lhes oferecem verossimilhança associada a noções de ordem pública, autoridade, religião, forças armadas etc. - , a notícia do golpe no país vizinho segue compondo um quadro explicativo de natureza argumentativa, em texto longo, certamente, como se disse, elaborado por Correspondente ou Enviado Especial, sempre de acordo com as características formais de Panorama.

A sub manchete que encabeça a face aprofundada da notícia dá o sentido geral da argumentação que se seguirá: "Donde También Dos Más Dos Son Cuatro" (maio de 1964 :31). O leitor logo perceberá que se trata de desenvolver a informação noticiosa no sentido de apontar a causa determinante, de valor universal, para o acontecimento, a qual se coloca frente a interpretações concorrentes, supostamente embasadas em certa imagem do país vizinho, difundida por seus próprios intelectuais e meios de comunicação. $\mathrm{Ou}$ seja, trata o jornalista, sempre nos cânones ideológicos de seu ofício, de (re)constituir a verdade dos fatos na notícia internacional, para uma correta orientação da Opinião Pública de seu país, certamente tendo em vista, direta ou indiretamente, o contexto político interno, conjunturalmente situado-significado no governo de Arturo Illia e na tutela militar do pós-1955. 
O texto distribui-se em duas colunas à direita da página, sendo que, em todo o canto esquerdo desta, vê-se uma coluna composta por imagens fotográficas do motim dos marinheiros no Rio de Janeiro. A abertura oferece uma citação:

'las cosas sucedieron aquí de manera tipicamente brasileña. Nada estaba organizado ni nadie estuvo a cargo de la conducción del movimiento revolucionario. Era como si varios arroyouelos hubiesen confluido sin proponérselo: de repente se había formado un río torrentoso...'

Imediatamente, a posição do autor da matéria assim se coloca sobre o texto citado:

en este comentario de un experto local sobre los acontecimientos que condujeron a la caida de João Goulart, hay dos elementos: uno es la opinión, sin duda justificada, de que el movimiento contra Goulart no se debió a una conspiración sistemática y orgánicamente coordinada; el otro encierra, implicitamente, el juicio de que, en el Brasil, las cosas siguen governadas por una extraña e inexplicable irracionalidad. Este último es erróneo. Por el contrario, lo que sucedió en el coloso del trópico obedeció a un proceso implacablemente racional y lógico (maio de 1964: 31).

A tipicidade nacional brasileira é, assim, chamada a compor o quadro analítico do acontecimento noticioso, na voz autorizada e verificativa de um "especialista local", com destaque inicial, nesse sentido, a uma ausência de coordenação conspiratória organizada na queda de Goulart e no gigantismo diferencial posto na expressão "colosso do trópico", o que seria retomado em edições posteriores do ano em Panorama. Todavia, para além de tal tipicidade e de seus efeitos reais, o jornalista enuncia a existência de uma causa profunda, posta em um "processo" de natureza racional, lógica e de validade universal, leia-se, igualmente válido para a realidade nacional argentina.

A argumentação prossegue sustendo que, se for considerada apenas a administração de Goulart, posta como "acidentada", teriam razão os analistas 
que colocavam o "fato revolucionário" de abril na conta da irracionalidade natural da vida pública brasileira. Todavia:

remontándose, en cambio, unos años más atrás, se conprenderá que lo ahora sucedido tiene la precisión inexorable de un silogismo: a ciertas premisas dadas siguió una conclusión previsible. João Goulart - y con él el Brasil entero - recogió, en amargura, los frutos que, en dulcedumbre, había sembrado Juscelino Kubistchek. Y de ese modo resultó que - pese a cuantos quieran pintar al Brasil como el país de los imponderables por excelencia - también allí dos más dos siguen siendo cuatro, igual que en cualquier otra parte del mundo... (maio de 1964:31).

Toda a sustentação analítica do fato restará embasada nesse enunciado, no qual a administração de Juscelino Kubistchek surge como origem de um processo sobre o qual é evocada a poderosa referência silogística como marca de universalidade. É fundamental notar que, em um mundo referencial consolidado para um público de formação superior, a figura e a administração de Juscelino Kubisthek, em sua herança varguista, encontram-se muito diretamente associados, por analogia, à figura e ao governo interrompido de Arturo Frondizi (1958-1962), da UCRI, em suas relações de aproximação com o peronismo. A sustentar a operação analógica deste quadro de referência, temse o desenvolvimentismo industrialista como política econômica daqueles governos e seus desdobramentos, positivos para alguns, negativos para outros, na cisão política reinante em ambos os países. Poder-se-ia talvez afirmar que um jornalista argentino, referindo-se a Kubistchek na construção da notícia internacional, está a apontar muito diretamente para um quadro referencial de significação disponível ao leitor argentino no qual se põe o frondizismo.

Nessa direção, o texto noticioso-informativo trata de colocar interpretações concorrentes do golpe na condição de "superficialidades", isto é, não propriamente equívocos, mas visões limitadas e sobretudo parciais, derivadas da consideração excessiva das peculiaridades brasileiras. O caráter arraigado dessa imagem de um país com vida pública marcada por irracionalidades, na qual se operariam "milagres" contrários às leis universais 
da Política e da Economia, determinava que, consumado o golpe, fossem buscadas explicações postas como imediatistas, dentre as quais se destacavam:

las relaciones entre la oficialidad y grupos políticos derechistas, la infiltración de los suboficiales por parte de extremistas de izquierda, la presencia de agitadores procedentes de China roja, las conexiones entre los líderes de la reforma agraria y la Iglesia Católica, la actuación de cabo Anselmo y la de Kubistchek y la de Teixeira Lott. Nombres, en general, y no hechos (maio de 1964:31).

E pode concluir a respeito o construtor da notícia:

todo eso es superficial. Lo que sucedió en el Brasil no es obra ni de comunistas ni de 'gorilas': no es producto de ningún maquiavélico plan de entrega del país al Kremlin o a Pekin, ni tampoco fruto de un golpe derechista, reaccionario o de corte fascista. Lo que sucedió no han sido sino los últimos estertores propios de un régimen económicamente desquiciado, financieramente en la quebra (maio de 1964:31).

E remetendo a um quadro referencial dramaticamente atualizado na Argentina:

sean quales fueren los futuros pasos que darán los que, en adelante, manejen la cosa pública en Brasil, deberán atenerse a esa realidad. Porque demás está decir que el desquicio económico y la quiebra financiera no se remedian con gestos demagógicos a la manera de los de João Goulart, tampoco se curan con pronunciamientos cívico-militares (maio de 1964: 31).

Assim, a cobertura de Panorama do golpe aparentemente articula duas operações de verossimilhança, paradoxalmente contraditórias e complementares, na construção de sentido que constitui aquele acontecimento como tal. De um lado, os enunciados predominantemente imagéticos remetendo a um quadro referencial calcado em imaginários anticomunistas básicos, composto na redação de internacional. De outro, a argumentação refinada do Correspondente ou Enviado Especial, na qual são rejeitadas ou conduzidas a um plano de superficialidade, as interpretações, tanto à esquerda quanto à direita - "entrega 
do país ao Kremlin/golpe reacionário de corte fascista" - no tocante à ruptura institucional, sobretudo no que tangeria à "real" causa desta.

A construção desta realidade constitui sua verossimilhança em um quadro de referência embasado em princípios clássicos do liberalismo econômico, ao sustentar a universalidade de leis relativas ao equilíbrio fiscal e à estabilidade monetária dos sistemas econômicos nacionais, situando-se, talvez mais ao fundo do quadro, a naturalização da ordem capitalista. Desse modo, infere-se diretamente da notícia, ou o golpe inauguraria novo regime que levasse em conta essa "realidade", ou não passaria de mero "pronunciamento cívico-militar", numa referência a um mundo pleno de significado negativo na cultura política hispano-americana. É o que vimos caracterizando como liberalismo profissional do campo, aqui posto na exigência de relativa complexidade analítica da notícia internacional, segundo os termos do pacto de leitura com a franja de público a que aquela potencialmente se destina.

Sempre nesse sentido, trata o jornalista de minimizar, ou mesmo excluir, a relevância das chamadas reformas de base como fator explicativo do golpe. Com base em operações de verificação, são delineados os fatos segundo os quais as reformas foram anunciadas apenas no início da segunda metade virtual do governo, não havia fundos públicos disponíveis para a concretização, sequer para um início razoável, da reforma agrária, assim como a estatização de refinarias privadas de petróleo em nada acrescentaria ao já estabelecido monopólio da PETROBRAS, que mantinha sob controle $90 \%$ do setor. Tampouco a troca, tida como excessiva e incoerente, de ministros da área econômica, Fazenda e Planejamento, poderia ser apontada, em si, como fator determinante do golpe:

ninguno de ellos, como resulta obvio, se convertió en el esperado 'hacedor del milagro' que era el de parar la inflación sin desatender, al mismo tiempo, los reclamos salariales de los sindicatos. No lo logró ni Celso Furtado, ni San Thiago Dantas, ni Moreira Salles, ni Calmon Almeida, ni Carvalho Pinto. Tampoco pudo hacerlo Ney Galvão, ni mucho menos 
lo hubiera podido el candidato (...) de Goulart, su desenfrenado cuñado Brizola (maio de 1964: 32).

O quadro referencial composto pela "lei" econômica segundo a qual verifica-se uma incompatibilidade absoluta entre combate à inflação e uma política salarial distribucionista, a qual atenderia aos reclamos de corporações sindicais, sustenta a verossimilhança do enunciado e da argumentação como um todo. A troca de ministros e a possibilidade de que o "desenfreado" cunhado do presidente assumisse uma das pastas é, assim, desdobramento do problema e não causa dele.

A argumentação conduz, assim, àquele que se põe como personagem central da narrativa noticiosa de Panorama sobre o golpe no Brasil, num papel singular de vilão, surpreendentemente retirado de um repisado João Goulart: Juscelino Kubistchek.

Uma página inteira, em duas colunas à esquerda, vai ser ocupada para construir as verdadeiras raízes do golpe de abril. Na metade direita, uma coluna com três fotos: nova cena de confronto entre militares e civis em rua do Rio de Janeiro, com uma densa coluna de fumaça em primeiro plano; abaixo, duas crianças com expressão reflexiva e olhar cabisbaixo que se informa tratar-se de João Vicente e Denise, filhos do presidente deposto e, abaixo, uma residência ostensivamente ampla, com telhado em chapa e árvores ao fundo, que se afirma ser a casa da família Goulart no exílio, na praia uruguaia de Solymar. A verificação imagética dos fatos era novamente construída em tons dramáticos e contrastantes.

Logo abaixo da sub manchete "Angustiosa Pobreza en el Nordeste" (maio de 1964 : 32), tem-se a caracterização introdutória da figura de Kubistchek e de seu governo, adjetivado de "futurista", com evidente ironia:

símbolo de superación de la crisis varguista, ese extraño político de múltiples rostros pudo haberse convertido también en la encarnación de la tan ansiada estabilidad económica brasileña; estabilidad que hacía tanto más falta cuanto mayores eran los males de una inflación endémica y de grandes desniveles económico-sociales entre las diversas regiones del país (maio de 1964: 32). 
Em operação verificadora, informam-se os dados acerca dos problemas reais que "poderiam" ter sido enfrentados por Kubistchek ao longo de seu governo, além da inflação e dos desequilíbrios regionais: uma balança de pagamentos com déficit crônico que então beiraria os 300 milhões de dólares anuais devido à queda mundial dos preços do café e ao crescimento acelerado da importação de petróleo, "para alimentar industrias secundarias que hiban surgiendo con la rapidez de los hungos después de la lluvia" (maio de 1964: 32). Na típica construção textual jornalística, ao realismo dos "fatos" sobrepõese uma metáfora na qual o surto industrial é associado à fragilidade passageira e deletéria dos fungos, seguindo-se assim a construção da verdade jornalística sobre os condicionantes da crise brasileira e do golpe (talvez Revolução): "no es menos verdad que esos déficit eran permanentemente compensados por créditos procedentes del Fondo Monetario Internacional, del Eximbank y de la banca privada norteamericana, pese a que el Brasil desatendía sistematicamente los reclamos de imponer um régimen de austeridad fiscal y de iniciar una política deflacionista”. E segue o aspecto central da verdade:

y no es menos verdad que levantar media docena de monumentales edificios en el corazón de la selva, para dar al conjunto el nombre de Brasília y convertirlo en la meca de los amantes de la arquitectura de vanguardia, le costó al país de las favelas y del campesino subalimentado la bicoca de vários centenares de millones de dólares (maio de 1964:32).

Um mundo referencial de pobreza generalizada nas cidades e nos campos, com favelas e camponeses famintos, é ativado para constituir o contraste que se torna fático com uma Brasília futurista, posta significativamente "em meio à selva". Era certamente uma construção com alto grau de veracidade para um certo público leitor argentino que associava, como se disse, o desenvolvimentismo de Kubistchek àquele de Frondizi e que talvez retivesse a imagem de uma Brasília como símbolo de sucesso e de expansão brasileira para o Oeste, o que, em certas visões referenciais, representava, ora fator de emulação, ora sério perigo geopolítico para o país, em sua rivalidade, 
posta ali como histórica, com o vizinho. A crise e o golpe vinham, assim, a contrastar essas visões com um outro mundo possível.

Nesse mundo, o desenvolvimentismo industrialista ocupava um lugar tanto negativo como fundamental, ainda mais quando associado a "demagogias eleitoreiras", como aquela posta no exemplo fático dos aumentos desproporcionais de salários para o funcionalismo público, concedidos por um Kubistchek em final de mandato. Nesse sentido, afirma-se:

los 2.500 millones de dólares que empresas extranjeras invirtieron en el Brasil durante el gobierno de Kubistchek contribuyeron a crear, a la par de una serie de actividades productivas útiles, otras que no hicieron más que sangrar el reservatorio de divisas, por la materia prima que requerían y los combustibles que consumían. Contribuyeron, eso sí, a atraer a la zona industrializada del país (...) a ingentes masas de obreros sin calificación, para cuyo bienestar social, especialmente en materia de vivienda, nada se hizo. E hicieron decaer la producción agrícola, pese a que esta seguía siendo la principal fuente de divisas del Brasil. Fue esta decadencia la que (...) agudizó hasta a llevarlo a extremos intolerables el antiguo problema social del nordeste brasileño (maio de 1964:32).

Acionam-se, assim, elementos fáticos para remeter a um mundo referencial em que se punha o debate público, no Brasil e na Argentina, senão em todo o subcontinente, entre o desenvolvimentismo industrialista, de variados matizes, e o liberalismo clássico, de corte agrarista, restando a crise brasileira e o golpe de abril enquadrados, sempre como fatos verdadeiros postos em acontecimentos verossímeis de um mundo possível verídico, em uma referência clara aos princípios desta última perspectiva político-econômica.

É com este lastro que se pode enunciar princípios prescritivos e, no limite, pedagógicos, no esclarecimento informativo da Opinião Pública argentina, segundo a ideologia profissional em que se referencia a construção da notícia, o que pode produzir como efeito a confirmação ou fortalecimento mobilizador da crença nestes princípios em certa parcela do público leitor:

una inteligente política agraria y una canalización de parte de aquellos vastos capitales extranjeros hacia la 
mecanización del agro, hubiesen redundado en un beneficio mayor del campesinado que utópicas reformas agrarias, consabidamente antieconómicas y contraproducentes en las agriculturas de tipo extensivo. El campesino en el latifundio es como un obrero de fábrica: darle su parcela de tierra es como declarar a aquél dueño de su torno.

E se conclui, lógica e factualmente, a racionalização:

lo que importa, en cambio, es elevar su nivel de vida [dos camponeses], implantando salarios justos y una legislación social severa. Todo ello no se hizo hasta ahora en el Brasil: el resultado es un odio que divorcia al campesinado de los terratenientes que ya no se miran como patronos y asalariados, sino como recíprocos usurpadores de su respectiva propiedad (maio de 1964: 32).

Remetendo a um mundo de referência constituído pelos princípios liberais clássicos, a perfeita logicidade que articula os enunciados pode justapor ao anticomunismo de referências emocionais - também mobilizado, como se viu, para compor a matéria - um mundo possível, isto é, verídico, no qual o conflito entre classes no campo aparece como resultado inapelável de opções político-econômicas irracionais, em um passado que se constitui narrativamente para a explicação da crise e do golpe noticiado, vale dizer, tornado acontecimento jornalístico.

Dados numéricos acerca do processo de desvalorização do cruzeiro são mobilizados como verificação do fato inflacionário ao longo do quinquênio do governo Kubistchek, sendo que, ao final deste, informa-se, a moeda brasileira era cotizada em 200/1 na relação com o dólar estadunidense, com tendência a acentuada instabilidade. E dessa forma se aponta, em suma, para as reais origens da ruptura institucional no Brasil: "una vez en el plano inclinado, el caminho cuesta abajo se recorre con rapidez: en el término de alredor de cuatro años, el signo monetário brasileño quedó reducido a una séptima u octava parte de su valor y, en los momentos de la crisis, el dólar llegó a cotizarse en el nível de los 2000 cruzeiros". E assim, "los gobiernos que sucedieron al creador de Brasília - el efímero de Quadros y el azaroso de Goulart - no constituyen, pues, 
desde el punto de vista de la política económica, capítulos independientes, sino coletazos últimos de un proceso iniciado anteriormente" (maio de 1964: 32-33).

As demais edições do ano de 1964 em que o Brasil é notícia internacional em Panorama seguem a construção deste mundo possível, no qual o golpe e o regime autoritário que se inicia ganham sentido com base em sua inserção em um processo fundamentalmente de natureza "econômica", sendo tal natureza referenciada, como se afirmou, em princípios liberais clássicos. Um grau de sucesso ou insucesso das medidas autoritárias/revolucionárias iniciais controle da inflação, ajuste fiscal, combate ao déficit na balança de pagamentos, cortes de subsídios ao setor industrial, debilitação política das demandas sindicais - poderá ser assim estabelecido para o público leitor argentino, tendo em vista os fatos e as referências que os constituem como acontecimentos.

\section{Referências}

ALSINA, M. A Construção da Notícia. Petrópolis: Vozes, 2009.

CANTIS, M. S. La Caída de los Tres Gobiernos Radicales. Buenos Aires: Centro de Estudios Unión para la Nueva Mayoría, 1995.

CAVAROZZI, M. Autoritarismo y Democracia (1955 - 2006). Buenos Aires: Ariel, 2009.

CHALABY, J. O Jornalismo Como Invenção Anglo-Americana. Comparação entre o Desenvolvimento do Jornalismo Francês e AngloAmericano (1830-1920). Rio de Janeiro: Mídia \& Jornalismo, 3V, 2003.

DE RIZ, L. La Política en Suspenso 1966/1976. Buenos Aires: Paidós, 2000.

DONGHI, T. H. La Democracia de Masas. Buenos Aires: Paidós, 2000.

GAMBINI, H. Historia del Peronismo. La Violencia (1956-1983). Buenos Aires: Vergara, 2008.

HABERMAS, J. Mudança Estrutural da Esfera Pública. Investigações Sobre Uma Categoria da Sociedade Burguesa. São Paulo: Ed. UNESP, 2014.

HALL, S. "A Redescoberta da 'Ideologia': o Retorno do Recalcado nos Estudos de Mídia”. In: RIBEIRO, A. P. G.; SACRAMENTO, I. (orgs.). 
Mikhail Bakhtin. Linguagem, Cultura e Mídia. São Carlos: Pedro \& João Ed., 2010 .

LLAIRÓ, M. de M. (comp.). El Gobierno de Arturo Illia y la Restauración Institucional. Las Relaciones Económicas Internacionales y la Crisis de Gobernabilidad (1963-1966). Buenos Aires: Ediciones Cooperativas, 2007.

O’DONNELL, G. Contrapuntos. Ensayos Escogidos sobre Autoritarismo y Democratización. Buenos Aires: Paidós, 2004.

PANDOLFI, R; GIBAJA, E. La Democracia Derrotada. Arturo Illia y su Época. Buenos Aires: Lumiere, 2008.

PARADISO, J. Um Lugar no Mundo. A Argentina e a Busca de Identidade Nacional. Rio de Janeiro: Civilização Brasileira, 2005.

POTASH, R. A. El Ejercito y la Política en la Argentina 1962-1973. De la Caída de Frondizi a la Restauración Peronista Primera Parte, 1962-1966. Buenos Aires: Ed. Sudamericana, 1994.

ROMERO, L. A. Breve Historia Contemporánea de la Argentina. Buenos Aires: Fondo de Cultura Económica, 2001.

ROUQUIE, A. Autoritarismos y Democracia. Estudios de Política Argentina. Buenos Aires: EDICIAL, 1994.

SÁNCHEZ, P. La Presidencia de Illia. Buenos Aires: Centro Editor de América Latina, 1983.

SCARZANELLA, E. "Entre dos Exilios: Cesare Civita, un Editor Italiano en Buenos Aires, desde la Guerra Mundial Hasta la Dictadura Militar (19411976)". Revista de Indias, n 245, 2009.

SCARZANELLA, E. Uma Editora Italiana na América Latina. O Grupo Abril (décadas de 1940 a 1970). Campinas: Ed. UNICAMP, 2016.

SCHUDSON, M. Descobrindo a Notícia. Uma História Social dos Jornais nos Estados Unidos. Petrópolis: Vozes, 2010.

SODRÉ, M. A Narração do Fato. Notas para Uma Teoria do Acontecimento. Petrópolis: Vozes, 2009.

Ulanovsky, C. Paren las Rotativas. Historia de los Medios de Comunicación en la Argentina. Diarios, Revistas y Periodistas (1920-1969). Buenos Aires: Emecé, 2005.

Recebido em: 27 de jlnho de 2019

Aceito em: 15 de dezembro de 2019 